\title{
INTERNALISASI PENDIDIKAN SEKS TERHADAP ANAK PEKERJA MIGRAN DI KABUPATEN BLITAR
}

\author{
Luvi Mei Anggraini( $\left.{ }^{(}\right)$, Irawan ( $\left.{ }^{2}\right)$, Joan Hesti Gita Purwasih $\left({ }^{*}\right)$ \\ ${ }^{123}$ Faculty of Social Sciences, Universitas Negeri Malang, East Java, Indonesia
}

\begin{tabular}{ll} 
ARTICLE INFORMATION \\
\hline Submitted & $: 26^{\text {th }}$ November, 2020 \\
Review & $: 14^{\text {th }}$ April, 2021 \\
Accepted & $: 21^{\text {st }}$ May, 2021 \\
Published & $: 07^{\text {th }}$ June, 2021 \\
Available Online & $:$ June, 2021 \\
KEYWORDS & \\
\hline
\end{tabular}

Role dysfunction; sex education; understanding of children.

\section{CORRESPONDENCE}

*E-mail: joan.hesti.fis@um.ac.id

\begin{abstract}
A B S T R A C T
Social changes that make society can influence the apparatus. Social changes have an impact on families in Indonesia. The narrower the workforce is coupled with the increasing needs of the family, the older the migrant worker works. As a result, the roles and functions of the family do not work properly. The impact is that the children commit juvenile delinquency. Like it or not, parents still guide their children and understand sexual education so that children do not engage in deviant behavior. This research method uses descriptive qualitative methods. The research focuses on how migrant workers instill sex education in children. There were six informants including 3 migrant workers and 3 migrant workers. Data techniques are observation and open interviews. The results of this study indicate that each migrant worker has a way of imparting sexual education to children. Differences in the cultivation of character education are motivated by several factors. One of them is the cultural factor of the country where the parents work. Furthermore, the acceptance of children in sex education and its application is almost similar. Children still maintain the limits of norms that apply in society.
\end{abstract}

\section{A. PENDAHULUAN}

$\mathrm{B}$ ekerja menjadi pekerja migran saat ini menjadi pekerjaan yang paling efektif dan menjanjikan. Hal tersebut dibuktikan dengan banyaknya cerita keberhasilan dari para pekerja migran yang menarik perhatian para calon pekerja migran. Kesuksesan para pekerja migran terlihat dari meningkatnya kesejahteraan hidup serta perubahan gaya hidup (life style) pekerja migran yang telah berhasil. Kesuksesan yang dialami oleh para pekerja migran menjadikan calon pekerja migran tertarik bekerja ke luar negeri (Karlina, Arif, \& Sodikin, 2017). Ditambah dengan sulitnya lapangan pekerjaan dan tuntutan pemenuhan kebutuhan hidup saat ini menjadi faktor utama bertambahnya minat terhadap sektor tersebut (Syamsudin, n.d.). Pekerja migran di Indonesia mayoritas menyasar negara tetangga seperti Malaysia, Hongkong, Taiwan, Singapura, Korea Selatan, Arab Saudi, Timur Tengah, atau negara belahan Eropa untuk dijadikan sebagai negara tujuan mereka bekerja. Fenomena maraknya pekerja migran mendapat respon positif dari pemerintah. Hal tersebut dibuktikan dengan adanya Undang-Undang yang mengatur tentang pekerja migran. Tenaga Kerja
Indonesia (TKI) menurut Undang-undang RI nomer 39 tahun 2004 adalah setiap warga negara Indonesia yang memenuhi syarat untuk bekerja di luar negeri dalam hubungan kerja untuk jangka waktu yang telah disepakati dengan menerima upah. Peraturan tersebut menunjukkan bahwa pekerja migran memiliki kurun waktu tertentu di dalam kontrak perjanjian yang telah disepakati. Kebijakan tersebut dibuat oleh pemerintah untuk memenuhi hak warga negara Indonesia dalam bekerja. Ditambah keberadaan pekerja migran membantu penambahan devisa untuk negara asal pekerja dan negara penerima para pekerja sehingga keadaan mereka cukup dibutuhkan oleh negara (Arfa \& Miswanto, 2016).

Menurut BN2PTKI, data penempatan PMI (Pekerja Migran Indonesia) tercatat sebesar 86.225 jiwa per bulan Januari-April 2019 dengan rincian lakilaki sejumlah 27.269 jiwa dan perempuan sejumlah 58.956 jiwa. Provinsi Jawa Timur merupakan penyumbang tertinggi pekerja migran dari tiap tahunnya. Tercatat pada tahun 2017-2018, provinsi Jawa Timur ada di peringkat pertama dengan jumlah TKI 9.514 jiwa. Memasuki tahun 2019, provinsi Jawa Timur tetap berada di urutan pertama dengan penempatan pekerja migran terbanyak se-indonesia. 
Tercatat 20.768 jiwa per bulan Januari-April (PUSLITFO, 2019).

Daerah yang cukup banyak mengirimkan pekerja migran yaitu Blitar. Blitar merupakan salah satu kota atau kabupaten di Provinsi Jawa Timur, Indonesia. Kabupaten Blitar memiliki 22 kecamatan dengan rincian 220 desa, 28 kelurahan, 759 dusun atau Rukun Warga (RW), dan 6.978 Rukun Tetangga (RT) yang tersebar di seluruh wilayah Kabupaten Blitar. Tercatat pada tahun 2016 jumlah pekerja migran yang berangkat ke luar negeri sebanyak 3.616. Tahun 2017 jumlah pekerja migran tercatat ada 4.476 jiwa, artinya ada peningkatan $20 \%$ jika dibandingkan tahun sebelumnya. Tahun 2019, Blitar menduduki peringkat ke-7 dalam penempatan pekerja migran berdasarkan Kabupaten atau Kota di Indonesia. Tercatat sebanyak 2.631 jiwa per bulan Januari-April (PUSLITFO, 2019). Negara tujuan yang paling diminati pekerja migran asal Blitar yaitu Hongkong, Taiwan, Malaysia, dan Korea Selatan. Adapun pekerjaan yang paling mendominasi disasar yaitu bidang informal sebanyak 3.396 (Blitar, 2018).

Fenomena pekerja migran pada mikro analisis menyebabkan permasalahan sosial, yaitu di tataran keluarga. Tidak optimalnya peran orang tua terjadi karena salah satu atau bahkan kedua orang tua dalam satu unit keluarga harus tinggal jauh dari rumah dalam kurun waktu yang lama. Akibatnya terjadi pergeseran peran orang tua. Kondisi ini diperparah ketika peran ibu yang kemudian hilang dalam keluarga karena menjadi pekerja migran. Akibatnya, ayah beralih menangani pekerjaan domestik seperti mengurus rumah tangga dan mengurus anak, sedangkan ibu berpindah dari pekerjaan domestik ke ranah publik, yaitu bekerja ke luar negeri (Eldayati, 2011). Anak pun mulai kehilangan asuhan dari orang tuanya, terutama ibu. Hal ini dapat menyebabkan pergantian pola asuh. Pergantian pola asuh cenderung diserahkan kepada generasi satu tingkat sebelum orang tua yaitu kakek nenek atau diserahkan kepada saudara kandung (Martsiswati \& Suryono, n.d.). Permasalahan lainnya yaitu komunikasi dalam keluarga pekerja migran. Apabila komunikasi mengalami hambatan akan sangat berdampak di dalam keluarga, karena unsur tersebut memiliki peran yang sangat penting (Djuwitaningsih, 2018).

Anak-anak pekerja migran sangat rentan terhadap dampak yang terjadi pada saat orang tua bekerja ke luar negeri. Dampak yang terjadi salah satunya yaitu kasus hamil di luar pernikahan. Menurut data dari $\mathrm{KPAl}$, terdapat 37 pasangan di bawah umur yang mengajukan dispensasi pernikahan dini dikarenakan hamil di luar nikah. Pernyataan tersebut dilatarbelakangi oleh pengaruh perkembangan media sosial yang dapat menjurus ke perubahan perilaku anak (Setyawan, 2017). Penelitian yang dilakukan oleh Widia A (2009) menunjukkan bahwa perilaku seks pranikah marak terjadi di daerah Pamekasan dikarenakan kurangnya pengawasan orang tua. Bentuk kenakalan lainnya seperti membolos sekolah, berjudi, dan minum-minuman keras (Widia, 2009). Penelitian lainnya yang ditelaah oleh Fatika, bentuk pergaulan bebas lainnya juga berupa bermain game, geng motor, dan pacaran. Penyebab dari adanya bentuk pergaulan bebas tersebut deisebabkan oleh lemahnya fungsi orang tua dalam hal afeksi, sosialisasi, proteksi, dan edukasi (Fatika, Syarifuddin, \& Rani, n.d.).

Fungsi edukasi orang tua terhadap anak memiliki peranan yang penting. Utamanya adalah pendidikan terkait dengan seks. Pemahaman anak terhadap pengetahuan seks sangat mempengaruhi perilaku seks pranikah dan selain itu perilaku seks dipengaruhi oleh faktor lain. Menurut WHO dalam survei tahun 2013 membuktikan bahwa pendidikan seks dapat mencegah perilaku seks pranikah. Hal tersebut berarti juga bahwa pemahaman pendidikan seks dapat mencegah secara preventif adanya penularan penyakit seksual lainnya (Pratama, Hayati, \& Supriatin, 2014). Pernyataan yang disampaikan oleh Wakil KPAI, Rita Pranawati (2017) bahwasannya penanaman nilai-nilai termasuk dalam proses edukasi terhadap anak tentang pendidikan seks serta pengawasan pergaulan anak sudah menjadi tanggung jawab orang tua (Setyawan, 2017).

Data pekerja migran di Blitar menempati posisi ke7 dalam urutan daerah tertinggi di Indonesia menjadikan keluarga pekerja migran di Blitar memiliki risiko mengalami disfungsi peran orang tua. Pergeseran peran antara ayah dengan ibu dimana ibu bekerja di ranah publik sedangkan ayah bekerja di ranah domestik. Meninjau kembali bahwasannya peran ibu sebagai sosok pendidik bagi anaknya. Tidak bisa dipungkiri, sebagian besar anak memiliki kedekatan secara emosional dengan ibunya (Nadhifa, 2018). Realitanya, peran ibu yang bekerja di ranah publik menjadikan anak renggang dalam hubungan secara emosional. Akibatnya, peran ibu yang sesungguhnya tidak berfungsi secara semestinya. Disfungsi peran orang tua tersebut akan berdampak terhadap kurangnya afeksi,proteksi serta edukasi orang tua terhadap anak. Dampak tersebut memunculkan bentuk perilaku menyimpang anak, salah satunya yaitu perilaku seks pranikah.

Berdasarkan latar belakang yang telah dipaparkan, tujuan umum dari penelitian ini adalah untuk memperoleh informasi baru tentang dunia pekerja migran. Tujuan khusus dari penelitian ini yaitu untuk mengetahui bagaimana proses internalisasi yang dilakukan oleh orang tua pekerja migran dalam mengajarkan anaknya, terutama dalam hal pendidikan seks dengan keterbatasan orang tua dalam melakukan interaksi secara langsung kepada anaknya. Hal ini penting dikaji untuk mengetahui bagaimana peran orang tua pekerja migran dalam mendidik anak masih berfungsi atau tidak. Selain itu dapat menjadi suatu informasi dan bahan evaluasi bagi orang tua dalam menguatkan ketahanan di dalam keluarga melalui pendidikan. Bagi pemerintah, hal ini sangat penting untuk menjadi perhatian agar sedikit lebih dekat dengan pendidikan seks melalui kurikulum pendidikan. Hal ini menjadi alasan yang kuat dikarenakan pendidikan seks terbukti dapat 
mencegah kasus kenakalan yang dilakukan oleh anak.

\section{B. METODE PENELITIAN}

$\mathrm{M}$ etode yang digunakan dalam penelitian ini adalah metode kualitatif deskriptif. Kualitatif deskriptif ini merupakan metode yang menghasilkan data berupa tulisan ataupun kata-kata dari sesuatu tindakan Deskriptif dalam penelitian ini berarti menjelaskan suatu permasalahan secara mendalam (Lexy J. Moeleong, 2018). Penjelasan meliputi proses internalisasi pendidikan seks terhadap anak pekerja migran di daerah Kabupaten Blitar.

Penelitian ini menggunakan desain penelitian dengan pendekatan studi kasus. Studi kasus termasuk di dalam analisis deskriptif dimana peneliti memilih satu kasus dengan sekelompok orang ataupun individu dan diselidiki secara mendalam dan tuntas sesuai dengan teknik penelitian yang ada. Tujuan dari studi kasus adalah menjawab masalah serta pertanyaan dari penelitian (Prihatsanti, Suryanto, \& Hendriani, 2018). Pendekatan ini memfokuskan kepada salah satu objek penelitian yang dijadikan satu kasus di dalam penelitian ini. Penelitian ini memilih 6 informan dengan rincian 3 informan orang tua serta 3 informan lainnya adalah anak-anak pekerja migran. Informan yang peneliti pilih yaitu orang tua dan anak dari keluarga pekerja migran yang bertempat di Kabupaten Blitar.

Teknik pengumpulan data menggunakan observasi. Observasi adalah suatu proses pengamatan secara mendalam yang sesuai dengan kontek yang dikaji oleh peneliti. Teknik kedua yaitu wawancara terbuka dimana peneliti mengajukan pertanyaan berkaitan dengan rumusan permasalahan penelitian dan dijawab secara jelas oleh informan dalam keadaan sadar.

\section{HASIL DAN PEMBAHASAN}

K ebudayaan masyarakat di Indonesia mengkategorikan keluarga dalam dua bentuk. Pertama yaitu keluarga inti. Keluarga inti atau nuclear family adalah keluarga yang terdiri dari ayah, ibu, dan anak. Keluarga inti memiliki anggota keluarga serta cakupan yang lebih kecil. Bentuk kedua yaitu keluarga besar. Keluarga besar atau disebut dengan extended family terdiri dari keluarga inti yang ditambah dengan keluarga lain. Keluarga luas memiliki beberapa kepala keluarga (Djuwitaningsih, 2018). Bentuk-bentuk keluarga di Indonesia memiliki setiap perbedaan dalam cara berkomunikasi antar individu serta fungsi di dalam menjalankan tugasnya masing-masing.

Keluarga adalah bagian terkecil dari suatu masyarakat. Keluarga adalah lingkungan yang pertama bagi anak-anaknya. Peran keluarga bagi anaknya sangatlah penting. Keluarga dapat dikatakan pula sebagai tolak ukur bagi suatu negara dalam capaian keberhasilan $\mathrm{Hal}$ ini dikarenakan anak menjadi generasi penerus bagi masa depan negara.
Melihat sudut pandang yang lain, keluarga merupakan sebuah sistem yang terdiri dari subsistem. Jika fungsi tersebut tidak seimbang, maka stabilitas di dalam keluarga akan mengalami keguncangan (Hidayati, Zuhdi, \& Islam, 2019).

Melalui hasil observasi dan wawancara yang dilakukan di lokasi penelitian, proses internalisasi yang dilakukan oleh orang tua terhadap anak terkait pendidikan seks dalam keluarga pekerja migran terdapat hasil yang bervariasi sebagai berikut.

\section{Disfungsi Peran Orang Tua}

Orang tua adalah seseorang yang ditemui anak pada saat pertama kali mereka lahir ke dunia. Orang tua juga sebagai penanggung jawab di dalam penghidupan sehari-hari keluarga. Peranan orang tua tidak hanya merawat, membimbing, dan mengawasi anak dalam proses perkembangan fisik. Orang tua juga perlu memperhatikan psikologis anak agar mereka dapat bertumbuh dengan mental yang sehat serta edukasi secara sosial. Tujuannya tidak lain adalah agar anak dapat berperilaku sesuai dengan nilai serta norma yang berlaku di masyarakat (Asriyah, Taftazani, \& S, n.d.). Menurut Alfred A dalam Asriyah, terdapat sembilan peranan orang tua terhadap anak seperti halnya, orang tua diharap berpenghasilan untuk memenuhi kebutuhan sandang,papan.dan pangan anak. Orang tua juga harus memberikan rangsangan demi perkembangan kecerdasan emosional, sosial, dan spiritual. Tak hanya itu, orang tua juga diharap menjalankan fungsi proteksi terhadap anak dari segala situasi (Asriyah et al., n.d.).

Peranan orang tua secara emosional dan sosial terhadap anak nyatanya bergeser ke peran ekonomi (Rochaniningsih, 2014). Dimana orientasi orang tua pada perubahan ini adalah kebutuhan ekonomi keluarga, termasuk kebutuhan anak. Perubahan keluarga yang terjadi seperti pertambahan kebutuhan sehari-hari menjadikan orang tua sangat berminat untuk bekerja sebagai pekerja migran. Ditambah lagi dengan sempitnya lapangan pekerjaan saat ini. Faktor pendorong lainnya yaitu peningkatan status sosial di dalam keluarga (Rahmawati, 2014).

Kondisi tersebut nyatanya terjadi dalam keluarga migran yang peneliti temukan di lapangan. Berbagai macam faktor yang melatarbelakangi orang tua bekerja sebagai pekerja migran yaitu permasalahan ekonomi keluarga. Terutama kebutuhan anak menyangkut biaya pendidikan. Kedua yaitu kebutuhan papan yang belum terpenuhi. Orang tua pada saat kondisi tersebut istilahnya masih menumpang di rumah orang tua. Kebiasaan orang Jawa, seseorang yang sudah menikah cenderung harus memiliki rumah sendiri untuk ditinggali oleh orang tua beserta anakanaknya. Perasaan malu dan sungkan menyelimuti orang tua yang masih tinggal bersama dengan ayah ibu atau mertua mereka. Kebiasaan yang sudah tertanam di dalam masyarakat Jawa ini menjadi salah satu alasan mengapa orang tua mau tidak mau harus bekerja ke luar negeri. Walaupun sebagian orang Jawa tidak mengikuti kebiasaan tersebut. 
Alasan pekerja migran untuk berangkat ke luar negeri menjadikan pengasuhan anak dialihkan sementara kepada kakek nenek ataupun saudara kandung. Pengalihan pengasuhan anak ini termasuk dalam faktor yang disebabkan karena situasi khusus yang mengakibatkan gagalnya fungsi orang tua. Hal ini akan berdampak terhadap lemahnya pertahanan anak serta dapat memunculkan perilaku seks pranikah atau kenakalan remaja lainnya dikarenakan peran dan fungsi orang tua tidak berjalan secara optimal.

Pergeseran orientasi peran orang tua pekerja migran sangat berdampak terhadap pengambilan keputusan. Keputusan ini menjadi sesuatu yang sangat dilematis bagi orang tua pekerja migran. Keputusan antara memenuhi kebutuhan ekonomi atau pemenuhan kebutuhan sosial dan emosional anak. Keputusan yang diambil orang tua sangat mengandung konsekuensi terhadap anak. Konsekuensi tersebut berlaku saat output anak terlihat baik atau buruk di dalam masyarakat.

Peran dan fungsi orang tua dalam keluarga pekerja migran seringkali mengalami kegagalan dalam menjalankan tugas. Banyak faktor yang mempengaruhi hal tersebut, seperti faktor dari diri orang tua serta faktor situasi. Menurut Silalahi (2010, p.186), faktor pribadi orang tua ditandai dengan tidak adanya kesadaran dari pihak ayah dan ibu akan fungsi perkawinan. Pergeseran peran ayah dan ibu serta dominasi kehadiran salah satu orang tua juga menjadi faktor kegagalan dalam menjalankan fungsi keluarga (Rochaniningsih, 2014).

\section{Pemahaman Pendidikan Seks Pranikah pada Keluarga Migran}

Penanaman nilai yang dimaksud salah satunya pendidikan seks yang masih tabu dibicarakan dengan sikap terbuka (Yahdi, 2010). Menurut Luthfie,R.E (2009), pendidikan seks itu sendiri adalah suatu ilmu yang membahas terkait dengan alat-alat reproduksi manusia, tingkah laku seksual, proses pembuahan hingga aspek kesehatan reproduksi lainnya. Menurut Bungin (2008) pendapat lain mengenai pendidikan seks yaitu pengetahuan yang menyangkut tentang alat kelamin. Bagaimana fungsi alat kelamin, pertumbuhan dan perkembangan yang terjadi, perubahan hormon-hormon yang menimbulkan birahi termasuk informasi yang berkaitan dengan pembuahan dan persalinan. Pendidikan seks sangat mempengaruhi perilaku seksual anak. Perilaku seksual anak salah satunya yaitu seks pra nikah marak terjadi karena disebabkan oleh minimnya pengetahuan anak terhadap pendidikan seks yang mengakibatkan anak mencoba hal-hal yang baru sehingga dapat menjurus ke dalam maraknya kasus hamil di luar nikah (Pratama et al., 2014).

Terkait konsep yang sudah dipaparkan peneliti menemukan gambaran pemahaman seks pranikah di kalangan orang tua dan anak-anak pekerja migran sebagai berikut. a. Internalisasi Pendidikan Seks dari Pekerja Migran

Menurut hasil observasi dan wawancara, setiap pekerja migran memiliki cara tersendiri untuk mendidik anak-anaknya tentang pendidikan seks. Meskipun terbentur dengan situasi dan kondisi yang ada, tetapi orang tua tetap berkewajiban untuk membimbing anak-anaknya. Alasan yang mendasar yang melatarbelakangi orang tua membimbing anak-anak mereka terutama dalam hal pendidikan seks, karena orang tua memiliki kesadaran diri bahwa orang tua tidak bisa secara langsung menjaga anak-anaknya agar terhindar dari pergaulan bebas. Oleh karena itu, orang tua yang bekerja sebagai pekerja migran tetap mengusahakan memberikan pendidikan dengan cara menasehati anaknya untuk tetap menjaga batasan, khususnya batasan berperilaku terhadap lawan jenis.

Batasan yang diberikan oleh anak pun bermacam-macam. Berdasarkan hasil dari wawancara, ibu selalu menekankan kepada anaknya terkait dengan bagian tubuh mana saja yang boleh dan tidak boleh disentuh orang lain. Area sensitif yang tidak boleh disentuh oleh orang lain meliputi wajah (terutama mulut), bagian dada, dan bagian intim. Bagian-bagian sensitif tersebut hanya boleh disentuh oleh anak itu sendiri. Kedua yaitu pada saat anak masih berusia kecil, anak ditekankan untuk tidak mandi secara bersamaan walaupun itu dengan saudara sepupu, selain itu anak dilarang telanjang setelah mandi. Harus berganti pakaian di dalam kamar mandi. Ketiga yaitu anak ditekankan harus tidur sendirian, walaupun suatu ketika terdapat acara keluarga dan tidur bersama di ruang tamu, hal tersebut tidak diperbolehkan. Bentuk pendidikan yang lain yaitu mengenalkan alat reproduksi kepada anak. Bagian tubuh mana yang dianggap aurat dan tidak boleh diperlihatkan kepada orang lain.

Pada saat anak memasuki usia remaja, pendidikan seks yang diajarkan oleh orang tua juga berbeda. Batasan-batasan yang diberlakukan dalam masing-masing ibu juga berbeda, seperti aturan dalam berpacaran. Informan pertama memperbolehkan anaknya berpacaran tetapi harus memperhatikan batasan dalam berperilaku terutama dengan lawan jenis seperti tidak boleh berciuman bibir, menyentuh bagian sensitif, hingga bersenggama. Batasan lainnya yaitu tidak boleh merahasiakan hubungan apapun kepada ibunya atau backstreet. Anak tidak boleh melakukan liburan bersama dengan pacar, walaupun berencana untuk menginap di tempat yang terpisah. Disisi lain perilaku seksual yang tergolong ringan lainnya seperti berpegangan tangan dan mencium area pipi masih diperbolehkan oleh orang tua.

Informan kedua, ibu tidak pernah melarang anaknya untuk berpacaran. Anak dibebaskan dalam hal berpacaran, keluar malam, berpergian dengan siapa saja, dan pulang jam berapa. lbu sudah memberikan kepercayaan penuh terhadap anaknya. lbu beranggapan bahwa tubuh anak sudah menjadi otoritas anak itu sendiri. Anak dianggap sudah mengerti baik buruk perilaku serta sudah memahami 
pendidikan seks yang diajarkan oleh orang tua maupun nilai norma yang sudah menjadi pegangan di sekitar masyarakat. Anak harus memiliki kesadaran diri pada saat melakukan perbuatan apapun serta harus mengerti batasan-batasan berperilaku.

Informan ketiga yaitu orang tua sangat membebaskan anaknya dalam hal berpacaran hingga melakukan hubungan seksual. Ibu menekankan kepada anak apabila pada saat melakukan hubungan seks pranikah, maka wajib menggunakan pengaman. Penggunaan pengaman pada saat melakukan seks sangat ditekankan kepada anak dikarenakan ibu lebih memperhatikan kesehatan reproduksi anak. Pencegahan preventif agar pasangan tidak menularkan penyakit kelamin dan pastinya dapat mencegah dari kejadian hamil di luar perkawinan atau MBA (marriage by accident).

Hasil wawancara tersebut dapat dianalisis bahwa batasan-batasan yang diberlakukan oleh orang tua terhadap anak bermacam-macam. Hal tersebut dipengaruhi oleh beberapa faktor. Faktor pertama yaitu pribadi orang tua itu sendiri. Bagaimana sifat serta kepribadian orang tua akan tercermin kepada peraturan-peraturan yang diberlakukan. Kedua yaitu orientasi orang tua. Kecenderungan orang tua terhadap pandangan terhadap suatu aspek. Baik aspek budaya ataupun agama. Sebagai contoh, informan satu tetap membatasi anak dengan aturan yang dibuat. Hal ini menunjukkan bahwa orang tua tetap memegang teguh nilai dan norma yang ada di masyarakat sekitar, utamanya budaya Timur.

Faktor ketiga yaitu latar belakang orang tua bekerja di negara tujuan. Terlihat pada pernyataan informan ketiga bahwa anak diperbolehkan melakukan hubungan seks pra nikah. Hal tersebut dilatarabelakangi oleh negara yang sekarang ditinggali adalah belahan Eropa. Disimpulkan bahwa orang yang tinggal disuatu negara dengan budaya yang berbeda, maka akan melahirkan pemikiran atau budaya baru. Kondisi ini tercermin dalam pemberlakuan peraturan bagi anak dalam berhubungan dengan lawan jenis.

Penanaman pendidikan seks tersebut secara terus menerus ditanamkan dan dibimbing melalui perantara maupun secara langsung. Perantara yang sering digunakan yaitu melalui telepon secara langsung atau percakapan via sosial media. Orang tua selalu bertukar kabar dengan anaknya dan disisipi dengan nasehat-nasehat untuk selalu mengingat batasannya dalam berperilaku. Cara yang kedua yaitu dengan cara berinteraksi langsung dengan anak. Pekerja migran biasanya mendapatkan hari cuti dalam masa bekerjanya. Hal tersebut dimanfaatkan oleh orang tua untuk pulang ke kampung halaman. Keadaan cuti tersebut dimaksimalkan oleh orang tua untuk menghabiskan waktu bersama anaknya agar orng tua lebih dekat dengan anak dan utamanya bisa lebih mengontrol serta menasehati anak dalam hal berperilaku.

\section{b. Pemahaman Anak Pekerja Migran terhadap} Internalisasi Pendidikan Seks

Pembentukan nilai pada anak memiliki 5 tahap. Pertama yaitu tahap menyimak. Tahap menyimak ini anak dengan aktif menerima stimulus. Tahap responding, anak sudah dapat merespons stimulus dalam bentuk respon nyata. Tahap memberi nilai ini ketika anak sudah dapat menerima respon dan dapat memahami makna yang terkandung di dalamnya. Tahap pengorganisasian nilai ini merupakan suatu tahap yang lebih kompleks dari tahap sebelumnya, anak sudah dapat menyusun sistem dengan pemahaman makna dari stimulus tersebut. Terakhir yaitu tahap karakterisasi nilai yaitu tahap ketika anak sudah dapat meyimpulkan mana nilai yang diterapkan atau tidak dalam pribadi anak (Sukitman, 2016).

Hasil dari wawancara kepada 3 informan lainnya yaitu anak-anak pekerja migran. Kaitannya dengan penerimaan pendidikan seks yang telah diberikan oleh orang tuanya serta implementasi pendidikan tersebut dalam kehidupan mereka sehari-hari. Informan keempat merupakan anak dari informan pertama. Anak mematuhi peraturan yang dibuat oleh ibunya, walaupun beberapa peraturan pernah dilanggar oleh si anak. Pelanggaran yang dibuat yaitu tidur santai bersama dengan saudara sepupu tetapi masih dalam konteks wajar. Bentuk kedua yaitu batasan dalam berpacaran.

Informan kelima adalah anak dari informan kedua. Hal yang terjadi malah sebaliknya. Ibu membebaskan penuh dan tidak membatasi dalam hal berpacaran, tetapi harus tetap dalam batas wajar, tetapi anak tidak pernah melakukan hal yang mengarah ke perilaku seksual. Hal tersebut dibuktikan dengan anak belum pernah berhubungan dengan lawan jenis atau berpacaran hingga saat ini.

Informan keenam merupakan anak dari informan ketiga. Penerapan peraturan yang diberlakukan oleh ibunya tidak serta merta dimanfaatkan oleh si anak. anak memang cenderung melakukan hubungan berpacaran, tetapi tetap memperhatikan batasan yang diberlakukan oleh norma lingkungan sekitar. la berpendapat bahwa menjaga keperawanan sampai saatnya menikah adalah hal yang penting, dikarenakan mitos orang Jawa khususnya di daerah sekitar, bahwa keperawanan seorang wanita terlihat pada saat prosesi temu manten. Prosesi tersebut dilakukan dengan mempersatukan kembar mayang yang dibawa oleh pendamping temanten. Apabila janur yang dibawa oleh pendamping temanten pada saat prosesi tersebut layu, maka pertanda bahwa temanten wanita sudah tidak perawan. Terlepas dari kebenaran mitos tersebut, si anak tetap menjaga batasannya sendiri sesuai dengan norma yang berlaku.

Hasil dari wawancara tersebut dapat dianalisis bawah terdapat beberapa faktor yang melatarbelakangi pemahaman serta penerapan dalam kehidupan sehari-hari anak yaitu lingkungan sekitar. Lingkungan anak dimana ia tinggal dan pertemanan sangat mempengaruhi perilaku anak. Terlepas dari 
peraturan serta batasan orang tua yang telah diberlakukan. Lingkungan yang baik maka pergaulan bebas memiliki kemungkinan kecil untuk dilakukan anak. Begitu juga dengan circle pertemanan anak. Faktor kedua yaitu kebudayaan. Kebudayaan setempat berfungsi sebagai kontrol sosial. Hal tersebut dibuktikan dengan informan keenam bahwasannya orang tua memberikan kebebasan yang sebebas-bebasnya terkait dengan hubungan seks, tetapi dengan adanya budaya setempat, menjadikan kontrol bagi anak untuk tidak melakukan perilaku seks diluar pernikahan.

\section{Pendidikan Seks Pranikah dalam Perspektif Antropologi Keluarga}

Keluarga adalah salah satu institusi sosial yang dapat dilihat secara perspektif sosiologis-antropologis. Keluarga dapat menjadi orientasi kajian antropologi. Salah satu alasan yang melatarbelakangi adalah individu yang hidup berkelompok yang memiliki masing-masing tugas dan dilatarbelakangi oleh persamaan pertalian darah serta termasuk di dalam kelompok kekerabatan. Tak hanya itu, keluarga merupakan institusi sosial yang sangat reaktif terhadap perubahan-perubahan yang terjadi (Saifuddin, 2006).

Tidak dapat dipungkiri, bahwa masyarakat saat ini tengah mengalami banyak perubahan sosial. Perubahan sosial berdampak kepada keluargakeluarga di Indonesia. Perubahan yang terjadi berpengaruh terhadap aspek ekonomi serta kesejahteraan di dalam keluarga menjadi terganggu. Keluarga saat ini tak dapat menjalankan peran serta fungsi di dalam keluarga secara optimal. Hal tersebut berdampak terhadap perilaku menyimpang anak seperti hal nya fenomena seks pranikah.

Pemahaman serta penerapan pendidikan seks yang diajarkan oleh orang tua tidak serta merta dipatuhi ataupun dilanggar. Mereka tetap memfilter nilai-nilai apa yang menurut mereka baik atau buruk. Proses pembentukan nilai sudah sampai pada tahap karakterisasi nilai. Dimana anak sudah dapat mengerti makna nilai tersebut, mengatur secara sistematis, dan akhirnya menyaring mana yang diterapkan didalam kehidupan sehari-hari dan mana yang tidak. Kepatuhan ataupun pembangkangan anak dipengaruhi oleh faktor-faktor. Pertama yaitu faktor lingkungan. Lingkungan dapat berarti lingkungan sekitar atau circle pertemanan Dimana anak itu tinggal maka lingkungan yang baik dan sehat akan membentuk perilaku yang baik pula. Kedua yaitu faktor kebudayaan sekitar. Fungsi budaya salah satunya yaitu sebagai kontrol sosial. Walaupun orang tua tetap membebaskan anak, tetapi anak tetap berperilaku sesuai norma masyarakat.

Kajian keluarga dan pendidikan seks pada penelitian ini dapat menggunakan sudut pandang etik dan emik. Etik itu sendiri terbagi menjadi dua, yaitu etik peneliti dan etik informan. Etik peneliti merupakan sudut pandang yang digunakan peneliti dimana pemikiran peneliti sudah terjebak secara teoritis. Tidak dapat dipungkiri, peneliti sudah memiliki asumsi tersendiri sebelum terjun ke lapangan. Kedua, yaitu etik dari informan. Etik informan merupakan data yang diperoleh dari informan yang dimana data tersebut merupakan jawaban ideal yang keinginan peneliti. Jadi, data yang dihasilkan bukanlah data yang bersifat empiris (Amady, 2015).

Kajian pendidikan seks dalam penelitian ini menggunakan sudut pandang etik peneliti. Alasan tersebut dikarenakan peneliti memiliki pengalaman yang serupa dengan fokus penelitian. Hal tersebut dipaparkan dari beberapa informasi dari sudut pandang anak seperti tindakan yang dilakukan oleh informan terkait dengan pendidikan seks yang diberikan oleh ibu serta batasan-batasannya. Kedua yaitu tradisi temu manten yang disampaikan oleh informan. Data yang diperoleh diolah sehingga menghasilkan sebuah analisis peneliti bahwa tradisi tersebut berfungsi sebagai kontrol bagi informan itu sendiri dan sosial dalam melakukan sebuah tindakan. Terlepas dari perilaku menyimpang yang dilakukan oleh informan.

Kedua yaitu pendidikan seks dapat di analisis melalui bentuk nilai dan norma setempat. Nilai dan norma setempat dapat melahirkan gaya orang tua dalam mendidik anak. secara budaya setempat, terutama Jawa, pendidikan seks sudah ditanamkan kepada anak pada masa kecil, penanaman tersebut bersifat pengenalan. Memasuki masa remaja, orang tua masih belum memberikan tahap lanjutan kepada anak. Konstruksi masyarakat Timur yang menganggap hal itu tabu sangat mempengaruhi cara bersikap dan berperilaku dalam keluarga. Konstruksi sosial inilah yang melahirkan adanya ketidakterbukaan orang tua kepada anak dan berdampak terhadap kurangnya edukasi terhadap anak.

Akan tetapi, di sisi lain, terdapat orang tua pekerja migran yang sangat membebaskan perilaku seks pranikah. alasan tersebut selain dilatarbelakangi oleh nilai budaya setempat (negara asal pekerja migran bekerja), juga didasari oleh pengetahuan dan sains. Orientasi orang tua tidak lagi berbicara tentang nilai dan norma setempat anak tinggali, melainkan cara anak agar tetap terjaga kesehatan secara reporduksi dan mencegah secara preventif adanya kehamilan di luar pernikahan. Gaya mendidik orang tua tersebut sudah terintegrasi dengan budaya Barat.

Salah satu fungsi kebudayaan dalam kasus ini yaitu sebagai kontrol sosial. Artinya bahwa budaya dapat mengendalikan perilaku individu maupun kelompok dalam masyarakat. Penanaman nilai seks dari orang tua ke anak memang dapat melahirkan perilaku baik atau buruk terlepas dari batasan-batasan yang diberlakukan orang tua. Hal tersebut tergantung pada masing-masing individu. Akan tetapi, pada tahap proses pembentukan karakter, anak sudah sampai ke tahap pemahaman makna nilai, pengorganisasian nilai, serta penyaringan nilai. Hal ini dibuktikan dalam penerapan nilai seks anak ke dalam kehidupan seharihari yang masih tetap memegang teguh nilai norma sekitar. Salah satu alasannya yaitu karena anak 
berada di lingkungan masyarakat Timur. Dimana masyarakat masih dapat memberikan sanksi sosial terhadap perilaku meyimpang yang dilakukan oleh individu tersebut.

\section{KESIMPULAN}

$\mathrm{K}$ ondisi keluarga migran yang mengalami disfungsi peran dapat berdampak terhadap fungsi orang tua terhadap anak. Terutama fungsi orang tua dalam mengedukasi anak terkait dengan pendidikan seks. Akan tetapi, orang tua tetap mengusahakan meluangkan waktu kepada anak untuk tetap mendidik anak dengan memberikan batasan-batasan berperilaku. Perantara dalam proses menanamkan pendidikan seks berupa interaksi secara langsung pada saat orang tua mengambil cuti bekerja ataupun melakukan pengawasan secara berkala melalui telepon.

Internalisasi pendidikan seks yang dilakukan oleh orang tua kepada anak pekerja migran memiliki bermacam aturan serta batasan-batasan yang diberlakukan. Batasan yang diberlakukan oleh orang tua memiliki banyak perbedaan. Hal tersebut dilatarbelakangi oleh beberapa faktor. Faktor kepribadian orang tua itu sendiri. Kedua yaitu faktor orientasi orang tua terhadap pandangan hidup. Baik orientasi orang tua lebih ke hal agama atau budaya. Orientasi pandangan hidup tercermin di dalam peraturan yang diterapkan kepada anak. Ketiga yaitu faktor kebudayaan dari negara asal orang tua bekerja juga. mempengaruhi pemikiran, pandangan hidup, serta cara membimbing anak terutama di dalam pendidikan seks.

Penanaman yang diberikan orang tua tidak serta merta diterapkan dalam kehidupan sehari-hari oleh anak. Kewajaran anak dalam melanggar peraturan masih terjadi walaupun dalam batas wajar. Anak berperilaku sesuai dengan nilai dan norma masyarakat setempat. Penanaman nilai seks dari orang tua tetap memliki filter tersendiri oleh anak. Anak tetap menyaring mana nilai seks yang diterapkan ataupun tidak. Faktor yang melatarbelakangi adalah faktor budaya. Faktor budaya setempat menjadi salah satu kontrol sosial dalam berperilaku.

\section{E. UCAPAN TERIMAKASIH}

U capan terimakasih ditujukan kepada Universitas Negeri Malang atas kesempatan peneliti untuk menulis jurnal. Penelitian ini merupakan hasil untuk skripsi peneliti. Kedua kalinya penulis sampaikan terimakasih kepada para informan serta pembimbing dalam pembuatan jurnal ini.

\section{DAFTAR PUSTAKA}

Amady, M. R. El. (2015). ETIK DAN EMIK PADA KARYA ETNOGRAFI. Jurnal Antropologi:Isu-Isu Sosial Budaya, 167-189.

Arfa, D., \& Miswanto. (2016). PERDAGANGAN DAN PENYELUNDUPAN PEKERJA MIGRAN INDONESIA DI MALAYSIA. Jurnal Antropologi:Isu-Isu Sosial Budaya, 18(1), 1-11.

Asriyah, P. W., Taftazani, B. M., \& S, M. B. (n.d.). 37 PERANAN ORANG TUA TERHADAP PERILAKU ANAK SEBAGAI PEMIRSA TELEVISI DIRUMAH. 3, 155-291.

Blitar, P. (2018). JUMLAH TKI ASAL KABUPATEN BLITAR YANG BERANGKAT KE LUAR NEGERI SELAMA 2017 MENINGKAT. Diambil dari https://www.blitarkab.go.id/2018/01/08/jumlah-tki-asal-kabupatenblitar-yang-berangkat-je-luar-negeri-selama-2017-meningkat/

Djuwitaningsih, E. W. (2018). POLA KOMUNIKASI KELUARGA TENAGA KERJA WANITA (TKW). Jurnal Komunikasi dan Opini, 22, 64-74.

Eldayati, E. (2011). Pergeseran Peran Dalam Keluarga Tkw (Studi Kasus Ds Karanggayam Kab Banyumas).

Fatika, B. D. A., Syarifuddin, I., \& Rani, A. P. (n.d.). PERGAULAN ANAK YANG ORANGTUA SEBAGAI TENAGA KERJA INDONESIA (TKI) (Kasus di Desa Gelogor Kecamatan Kediri Kabupaten Lombok Barat). 1-12.

Hidayati, A., Zuhdi, M. S., \& Islam, B. K. (2019). Pengaruh Keluarga ( TKI ) Terhadap Perilaku Disiplin Belajar Siswa SD Di Kabupaten Tulungagung. 6(2), 157-164.

Karlina, E., Arif, M., \& Sodikin. (2017). PENGARUH BEKERJA DI LUAR NEGERI TERHADAP TINGKAT EKONOMI DAN PERCERAIAN. SOSIO DIDAKTIKA, 4 (1).

Lexy J. Moeleong. (2018). Metode Penelitian Kualitatif (Cetakan Ke). Bandung: PT Remaja Rosdakarya.

Martsiswati, E., \& Suryono, Y. (n.d.). Peran Orang Tua dan Pendidik dalam Menerapkan Perilaku Disiplin terhadap Anak Usia Dini. Jurnal Pendidikan dan Pemberdayaan Masyarakat, 1(November 2014), 187198.

Nadhifa, A. (2018). PERAN IBU DALAM MENDIDIK ANAK MENURUT AL-QUR'AN (Kajian Para Musafir Terhadap Q.S Al-Ahqaf (46): 15-18). UNIVERSITAS ISLAM NEGERI MAULANA MALIK IBRAHIM MALANG.

Pratama, E., Hayati, S., \& Supriatin, E. (2014). HUBUNGAN PENGETAHUAN REMAJA TENTANG PENDIDIKAN SEKS DENGAN PERILAKU SEKS PRANIKAH PADA REMAJA DI SMA Z KOTA BANDUNG. Jurnal 
IImu Keperawatan, II(2), 149-156.

Prihatsanti, U., Suryanto, \& Hendriani, W. (2018). Menggunakan Studi Kasus sebagai Metode IImiah dalam Psikologi. Buletin Psikologi, 26, 126-136.

PUSLITFO, B. (2019). DATA PENEMPATAN DAN PELINDUNGAN PMI PERIODE APRIL 2019.

Rahmawati. (2014). PERGESERAN PERAN DOMESTIK PADA KELUARGA TKW DI DESA SASAHAN KECAMATAN WARINGIN KURUNG KABUPATEN SERANG.

Rochaniningsih, N. S. (2014). THE IMPACT OF THE SIFT OF FAMILY ROLE AND FUNCTION ON TEENAGER 'S DEVIANT BEHAVIOURS. 59-71.

Saifuddin, A. F. (2006). Keluarga dan Rumah Tangga: Satuan Penelitian dalam Perubahan Masyarakat. ANTROPOLOGI INDONESIA, 30, 247-253.

Setyawan, D. (2017). Hamil Duluan, Puluhan Anak di Bawah Umur Minta Dinikahkan. Diambil dari KPAl website: https://www.kpai.go.id/berita/kpai-hamil-duluan-puluhan-anak-di-bawah-umur-minta-dinikahkan

Sukitman, T. (2016). INTERNALISASI PENDIDIKAN NILAI DALAM PEMBELAJARAN (UPAYA MENCIPTAKAN SUMBER DAYA MANUSIA YANG BERKARAKTER). Jurnal Pendidikan Sekolah Dasar, 2.

Syamsudin, G. A. (n.d.). DAMPAK POLA ASUH IBU SEBAGAI TENAGA KERJA WANITA (TKW) TERHADAP KEPRIBADIAN REMAJA. Perempuan dan Anak, 1(2), 2017.

Widia, H. (2009). KENAKALAN ANAK YANG DITINGGAL ORANG TUA SEBAGAI TKI KE LUAR NEGERI (Studi Kasus di Kecamatan Pasean Kabupaten Pamekasan-Madura). Universitas Negeri Malang.

Yahdi, M. (2010). FUNGSI PENDIDIKAN ISLAM DALAM KEHIDUPAN MANUSIA. 13, 211-225. 